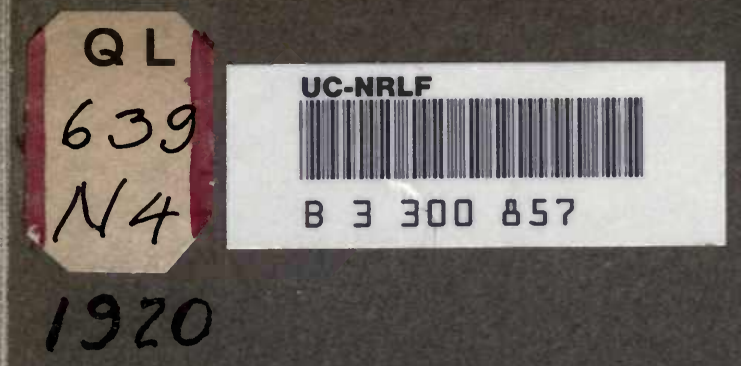



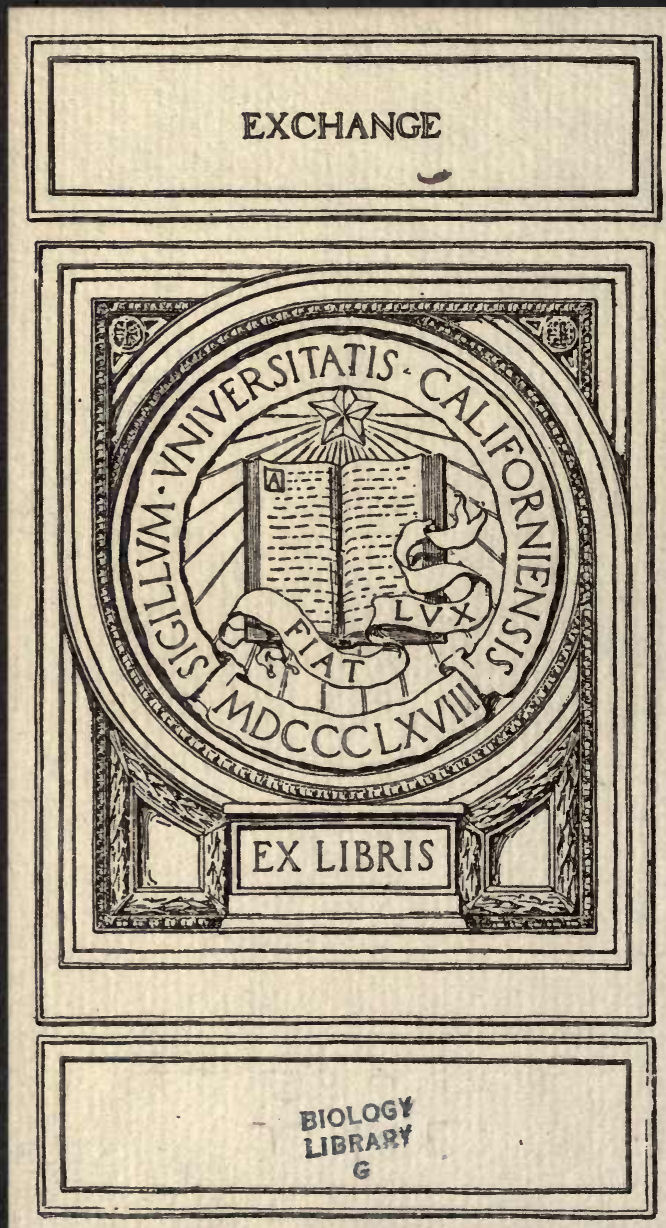


\section{MAP $15: 972$}

\section{HE CHEMICAL COMPOSITION OF THE OVARIES}

OF THE

\section{FRESH WATER GAR, LEPIDOSTEUS}

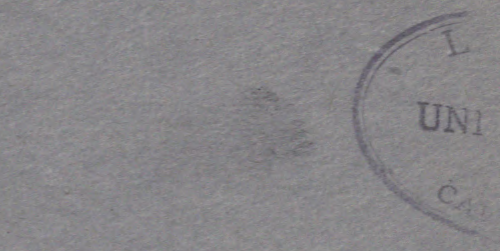

$\mathrm{BY}$

ERWIN ELLIS NELSON, A.B., B.S., A.M., (with Dr. C. W. Greene)

Thesis Submitted in Partial Fulfilment OF THE REQUIREMENTS FOR THE

Degree of

Doctor OF PHILOSOPHY

IN THE

Graduate School

OF THE

UNIVERSITY OF Missouri

1920 



\section{THE CHEMICAL COMPOSITION OF THE OVARIES}

OF THE

FRESH WATER GAR, LEPIDOSTEUS

ERWIN ELLIS NELSON, A.B., B.S., A.M., (With Dr. C. W. Greene) 
QL639

N4

siolous 


\title{
THE CHEMICAL COMPOSITION OF THE OVARIES OF FRESH WATER GAR, LEPIDOSTEUS.*
}

\author{
Br ERWIN E. NELSON† AND CHARLES W. GREENE.
}

(From the Department of Physiology and Pharmacology, Laboratory of Physiology, University of Missouri, Columbia, and the Biological Station of the United States Bureau of Fisheries, Fairport.)

(Received for publication, September 10, 1921.)

\section{INTRODUCTION.}

The data herein reported were obtained in the summer of 1917 as a part of the results of a study of fresh water fishery products undertaken with a view to extending the food sources available as meat substitutes. Gar eggs are of similar size and color to sturgeon eggs and have been unsuccessfully used as adultering substitutes for sturgeon eggs for caviar. The gar eggs do not retain their color in caviar processing and are not pleasing, in fact are positively objectionable, in flavor.

Chemical analyses have not previously been reported for gar roe. In fact there is a dearth of analyses of either roe or of ovaries of American fishes. Greene (1921) has analyzed the ovaries of the king salmon, and there is a single analysis of shad roe in Atwater's paper (1888.) Greene has followed the development of the salmon ovaries which occurs during the spawning migration. There is a great increase in egg mass with corresponding accumulation of protein and lipoids in the egg yolk, of which he presents evidence to show is derived from a corresponding storage in the muscles.

* Published by permission of the United States Commissioner of Fish and Fisheries.

† The data of this paper were used in part in the dissertation presented by Mr. Erwin E. Nelson for the degree of Doctor of Philosophy, University of Missouri, 1920.

University Fellow in the Graduate School, University of Missouri, 1916-18. 
In Europe a number of workers, chiefly German, have studied the composition of roe and caviar. The earlier literature is given in Atwater's monograph on the food fishes of America (1888). More recent papers are those of Buttenberg (1900-02), Rimini (1904), Farnstein (1903-04), Albu and Neuberg (1906), and Weitzel (1916). Tangl and Farkas (1904) followed the changes in composition of the fish egg with development of the embryo. Solberg (1906) analyzed codfish roe. König and Grossfeld (1913) made a very complete study of the use of fish roe as food, taking up in considerable detail the proteins, fats, and extractives.

\section{Material and Methods.}

Our samples of gar ovary were obtained from twelve specimens of Lepidosteus platystomus and one sample of Lepidosteus osseus. We did not secure samples of the larger southern species, the alligator gar, Lepidosteus tristoechus.

The method followed is essentially that perfected by Janney (1916) and used by C. H. Greene (1919) in his study of the extractives of the muscle of the king salmon. The samples of tissue for analysis were in all cases taken fresh, generally while still physiologically alive. Samples of the ovaries were placed in weighed glass-stoppered bottles, weighed at once, and transferred to casseroles and extraction with hot alcohol was begun at once, or they were covered with 95 per cent alcohol and sealed with hard .paraffin for transportation.

Samples for the determination of water were taken at the same time and weighed at once, then dried to constant weight at $105^{\circ} \mathrm{C}$. Water determinations were generally made in duplicate.

The analysis of the samples was carried out in the following manner: the sample and the alcohol covering it were transferred quantitatively to a porcelain casserole of about $300 \mathrm{cc}$. capacity. The alcohol was brought to boiling to complete the coagulation of the proteins. It was then poured off into a wide mouthed short necked flask, and placed on the water bath. Subsequent alcohol and water extracts were placed in this flask, which was kept on the water bath. If the sample were very fat, two or three preliminary extractions with ether were made. The sample was next extracted with boiling water in 50 to $100 \mathrm{cc}$. portions, at least eight extractions being made. The residue was then 
washed with 95 per cent alcohol and transferred to a Gooch crucible. The crucible was placed in a Greene's (1909) modified Soxhlet apparatus and extracted continuously with 95 per cent alcohol for 12 hours. This was followed with absolute alcohol for 12 hours, and then ether for from 18 to 24 hours. After the alcohol-ether extraction was complete the residue was transferred to a weighing vial, dried to constant weight at $105^{\circ} \mathrm{C}$, and weighed. This fraction appears in the tables as the protein residue.

The preliminary ether extract, the ether from the Soxhlet, and the ether-soluble material obtained from the alcohol-water extracts as described below, were evaporated and dried at $50^{\circ} \mathrm{C}$. and $75 \mathrm{~mm}$. of mercury in a vacuum oven. The oily material was dissolved in dry ether, filtered into weighing vials, and dried to constant weight in the vacuum oven. This is the lipoid fraction of the tables. At this point there was generally a small amount of material which was insoluble in the ether. This was dissolved in water and added to the alcohol-water extracts as described below.

The alcohol and water extracts were combined and evaporated to dryness on the water bath. The dry residue was then extracted with ether, and the ether-soluble material added to that from the preliminary ether extraction and the Soxhlet extraction as mentioned in the preceding paragraph. The residue insoluble in ether was taken up with water and made up to $250 \mathrm{cc}$. This solution contains the extractives. $100 \mathrm{cc}$. were evaporated to dryness in a platinum shell, weighed, ashed, and weighed again. The water-soluble solids, and the ash of the water-soluble solids were obtained from these figures.

Total nitrogen of the extractives was determined in an aliquot by Gulick's modification of the Folin-Farmer colorimetric method (1914).

Creatine was determined in $10 \mathrm{cc}$. aliquots by dehydrolysis and calculated as creatinine (Folin, 1914). The 10 cc. samples were evaporated to dryness on the water bath with $10 \mathrm{cc}$. of $\mathrm{N} \mathrm{HCl}$ and a bit of metallic lead, and the residue taken up quantitatively with hot water and washed into a $25 \mathrm{cc}$. volumetric flask. $10 \mathrm{cc}$. of saturated picric acid and 1 cc. of 10 per cent $\mathrm{NaOH}$ were added, the mixture was cooled at the tap, and allowed to stand. The necessary amount of standard creatinine solution 
was placed in a similar flask and treated with $\mathrm{NaOH}$ and picric acid in the same manner. At the end of 10 minutes both flasks were filled to the mark with distilled water and the readings taken in a Duboscq colorimeter. All determinations were made by daylight. The standard creatinine was isolated from urine by Benedict's method (1914) and checked against a sample of pure creatinine from Dr. Myers' laboratory. The values as recorded in the tables of this paper are in terms of creatine obtained by multiplying the creatinine determination by the factor 1.16 .

The amino nitrogen of the extractives was obtained by the method of Van Slyke (1912) using the micro-apparatus. ${ }^{1}$

\section{Protocols with Descriptive Data for Chemical Samples.}

Sample C11.-Fish 18. Lepidosteus platystomus ovary. Length of fish $52 \mathrm{~cm}$., weight $385 \mathrm{gm}$. Weight of ovaries $15.9 \mathrm{gm}$., diameter of ova $1.2 \mathrm{~mm}$. Weight of chemical sample $11.908 \mathrm{gm}$. Fairport, Iowa, July 25, 1917.

Sample C20.-Fish 19. Lepidosteus platystomus ovary. Length of fish $52 \mathrm{~cm}$., weight $435 \mathrm{gm}$. Weight of ovaries $30.5 \mathrm{gm}$., diameter of ova varied to a marked degree. "Many small white immature ova." Largest ova. $2.2 \mathrm{~mm}$., smallest $0.8 \mathrm{~mm}$. Weight of chemical sample $18.464 \mathrm{gm}$. Fairport, Iowa, July 25, 1917.

Sample C22.-Fish 32. Lepidosteus platystomus ovary. Length of fish $56.3 \mathrm{~cm}$., weight $535 \mathrm{gm}$. Weight of ovaries $48.3 \mathrm{gm}$., diameter of ova 1.7 $\mathrm{mm}$. Weight of chemical sample $17.858 \mathrm{gm}$. New Boston, Illinois, August. 25, 1917.

Sample C26.-Fish 29. Lepidosteus platystomus ovary. Ovary weight. $27 \mathrm{gm}$., diameter of ova $1.5 \mathrm{~mm}$. "Ovary filled with red fat." Weight of chemical sample $20.958 \mathrm{gm}$. Fairport, Iowa, August 16, 1917.

Sample C29.-Fish 35. Lepidosteus platystomus ovary. Length of fish. $57.5 \mathrm{~cm}$., weight $504 \mathrm{gm}$. Weight of ovaries $48.5 \mathrm{gm}$., diameter of ova 1.9 $\mathrm{mm}$. Weight of chemical sample $20.808 \mathrm{gm}$. New Boston, Illinois, August. 25, 1917.

Sample C36.-Fish 33. Lepidosteus platystomus ovary. Length of fish $58 \mathrm{~cm}$., weight $611 \mathrm{gm}$. Weight of ovaries $52.8 \mathrm{gm}$., diameter of ova 1.8 $\mathrm{mm}$. Weight of chemical sample $20.373 \mathrm{gm}$. New Boston, Illinois, August 25, 1917.

Sample C38.-Fish 34. Lepidosteus platystomus ovary. Length of fish $55.4 \mathrm{~cm}$., weight $619 \mathrm{gm}$. Weight of ovaries $72.5 \mathrm{gm}$., diameter of ova $2.0 \mathrm{~mm}$. Weight of chemical sample $20.059 \mathrm{gm}$. New Boston, Illinois, August 25, 1917.

${ }_{1}^{1}$ All total nitrogen and amino nitrogen determinations were made for us by Mr. Louis Gambee. 
Sample 41b.-Lepidosteus platystomus ovary. Mixed sample. "In salt, 1 to 6 . Roe immature, full of fat." Weight of chemical sample 20.071 gm. Received by express from New Boston, Illinois, September 26, 1917.

Sample 42a.-Lepidosteus osseus ovary. Weight of sample $22.958 \mathrm{gm}$. Weight of ovary estimated $500 \mathrm{gm}$. Received from New Boston, Illinois, by express November 12, 1917.

TABLE I.

Summary of Results of Analyses of Gar Ovaries.*

\begin{tabular}{|c|c|c|c|c|c|c|c|c|c|}
\hline \multirow{2}{*}{ No. } & \multirow{2}{*}{ Lipoid. } & \multirow{2}{*}{$\begin{array}{l}\text { Pro- } \\
\text { tein. }\end{array}$} & \multicolumn{5}{|c|}{ Extractives. } & \multicolumn{2}{|c|}{ Water, by } \\
\hline & & & Solids. & Ash. & $\begin{array}{l}\text { Total } \\
\text { N. }\end{array}$ & $\begin{array}{c}\text { Amino } \\
\mathrm{N} .\end{array}$ & Creatine. & $\begin{array}{l}\text { Differ- } \\
\text { ence. }\end{array}$ & $\begin{array}{l}\text { Determi- } \\
\text { nation. }\end{array}$ \\
\hline C11 & 11.3 & 15.7 & 2.08 & 0.56 & 0.217 & 0.056 & 0.0101 & 70.9 & 72.9 \\
\hline $\mathrm{C} 20$ & 14.0 & 23.8 & 2.75 & 0.49 & 0.218 & 0.049 & 0.0111 & 59.4 & 57.1 \\
\hline $\mathrm{C} 22$ & 12.4 & 26.3 & 1.13 & 0.31 & 0.291 & 0.028 & $\ddagger$ & 60.1 & 61.0 \\
\hline $\mathrm{C} 26$ & $20.6+$ & 23.3 & 1.27 & 0.28 & 0.130 & 0.038 & 0.0069 & 61.5 & 56.2 \\
\hline $\mathrm{C} 29$ & 17.4 & 25.6 & 1.09 & 0.27 & 0.077 & 0.023 & 0.0085 & 55.8 & 57.0 \\
\hline C36 & 14.4 & 27.9 & 1.21 & 0.54 & 0.074 & 0.017 & 0.0051 & 56.4 & 57.1 \\
\hline C38 & 17.9 & 24.8 & 1.21 & 0.25 & 0.076 & 0.044 & 0.0080 & 56.0 & 56.4 \\
\hline $41 a$ & 14.0 & 26.4 & 18.45 & 14.66 & 0.243 & 0.031 & 0.0082 & 41.1 & $\ddagger$ \\
\hline $41 b$ & 12.8 & 26.7 & 17.16 & 10.82 & 0.229 & 0.036 & 0.0097 & 43.3 & $\ddagger$ \\
\hline $42 a$ & 26.9 & 28.4 & 0.79 & 0.25 & 0.053 & 0.020 & Trace. & 43.9 & $\ddagger$ \\
\hline C63 & 17.3 & 26.3 & 1.15 & 0.51 & 0.091 & 0.015 & $\ddagger$ & 55.2 & $\ddagger$ \\
\hline C66 & 17.6 & 25.3 & 1.02 & 0.38 & 0.072 & Trace. & $\ddagger$ & 56.0 & $\ddagger$ \\
\hline C78 & 18.3 & 26.2 & 1.54 & 0.56 & 0.138 & 0.006 & $\ddagger$ & 54.0 & $\ddagger$ \\
\hline
\end{tabular}

* No. 42a is from Lepidosteus osseus, the remainder are Lepidosteus platystomus. All calculations are in terms of parts per $100 \mathrm{gm}$. of moist sample.

$\dagger$ Part lost.

$\ddagger$ Not determined.

Sample C63.-Lepidosteus platystomus ovary. Length of fish $61 \mathrm{~cm}$., weight of ovary $66.7 \mathrm{gm}$. Weight of chemical sample $24.095 \mathrm{gm}$. Hannibal, Missouri, July 30, 1920.

Sample C66.-Lepidosteus platystomus ovary. Length of fish $58.5 \mathrm{~cm}$., weight of ovary $91.65 \mathrm{gm}$. Weight of chemical sample $27.46 \mathrm{gm}$. Hannibal, Missouri, July 30, 1920.

Sample C78.-Lepidosteus platystomus ovary. Length of fish $55.8 \mathrm{~cm}$, weight of ovary $94.75 \mathrm{gm}$. Weight of chemical sample $28.28 \mathrm{gm}$. Hannibal, Missouri, July 30, 1920. 
DISCUSSION.

Lipoids.

The lipoid fraction in terms of the moist sample of ovary is comparatively large, from 15 to 20 per cent. In the single sample of Lepidosteus osseus, 42a, it reaches 26 per cent, which is higher than any value for fish ovary found in the literature. In the gar ovary, especially in the young stages, there is a deposit of fat in the supporting tissues which in some samples is quite considerable.

TABLE II.

Analyses Arranged in Series According to the Weights of the Ovaries.

\begin{tabular}{|c|c|c|c|c|c|c|c|}
\hline No. & $\begin{array}{c}\text { Weight } \\
\text { of ovary. }\end{array}$ & $\begin{array}{l}\text { Diameter } \\
\text { of ova. }\end{array}$ & $\begin{array}{l}\text { Length } \\
\text { of fish. }\end{array}$ & Lipoid. & Protein. & $\begin{array}{c}\text { Extrac- } \\
\text { tives. }\end{array}$ & Water. \\
\hline & gm. & $m m$. & $\mathrm{cm}$. & & & & \\
\hline C11 & 15.9 & 1.2 & 38.5 & 11.3 & 15.7 & 2.07 & 72.9 \\
\hline $\mathrm{C} 26$ & 27.0 & 1.5 & $*$ & $20.6 \dagger$ & 23.3 & 1.26 & 56.2 \\
\hline $\mathrm{C} 20$ & 30.5 & 2.2 to 0.8 & 43.5 & 14.0 & 23.8 & 2.70 & 57.0 \\
\hline $\mathrm{C} 22$ & 48.0 & 1.7 & 53.5 & 12.4 & 26.3 & 1.13 & 61.0 \\
\hline $\mathrm{C} 29$ & 48.5 & 1.9 & 60.4 & 17.4 & 25.6 & 1.09 & 57.0 \\
\hline C36 & 52.0 & 1.8 & 61.1 & 14.4 & 27.8 & 1.20 & 57.1 \\
\hline C63 & 66.7 & $*$ & 61.0 & 17.3 & 26.3 & 1.15 & 53.1 \\
\hline C38 & 72.0 & 2.0 & 61.9 & 17.9 & 24.8 & 1.21 & 56.4 \\
\hline C66 & 91.6 & $*$ & 58.5 & 17.6 & 25.3 & 1.03 & 56.0 \\
\hline C78 & 94.7 & $*$ & 55.8 & 18.3 & 26.2 & 1.54 & 53.9 \\
\hline $42 \mathrm{a}$ & $\ddagger$ & $\ddagger$ & $\ddagger$ & 26.9 & 28.4 & 0.79 & 43.9 \\
\hline
\end{tabular}

* Not recorded.

$\dagger$ The notes record that there was a large amount of extra-ovular fat in this ovary

$\ddagger$ Not recorded, but this was undoubtedly the oldest fish of the series. The ovary weighed several hundred grams.

The analysis of the entire ovary does not distinguish between this fat, which might be called extra-ovular, and the lipoids of the developing ovules with their increasing mass of cell yolk. The total egg yolk lipoids seem to increase as the eggs develop.

If one arranges the analyses in a series according to the weight of the ovaries, it is noted that in a general way the percentage of ether-soluble materials increases with the increase in weight, Table II. The parallelism between increase in weight, diameter of the ova, and length of the fish shown in this table is evidence that the increase in lipoids is in part at least due to growth of 
the ovary, and not to the accumulation of extra-ovular fat. The weight of the ovary is a fair criterion of the age of the ovary.

Because of the inability to differentiate between the source of the various lipoid fractions, it would seem that a more accurate picture of the metabolic changes might be gained by calculating the data on a fat-free basis. This has been done in Table III.

\section{Proteins.}

There is a rather close approximation in the values for the proteins, if Sample C11 and the single sample of Lepidosteus osseus, $42 \mathrm{a}$, be disregarded. C11 is a very much younger fish, if one may judge by the weight of the ovaries and the diameter of the ova. Greene (1918) showed for the salmon that the protein content of the ovary was remarkably constant throughout the period of late development. Sample C11 is an interesting case of an ovary which has not yet reached the average protein content for the species. Its water content is the highest of all the specimens examined. Sample $42 \mathrm{a}$ is obviously a much more mature specimen. It has the highest protein, 28.4 per cent, and the lowest water, 43.9 per cent, content of all the ovaries studied. This might be explained on the grounds of the difference in species. But Hatai (1917) has shown that in the white rat there is an increase in protein and.a decrease in water content of the whole body throughout the whole growth period. These facts, especially when taken in conjunction with the variations in the extractive fractions, argue for a more active stage of metabolism in the early growth period of the gar ovaries.

The average values for protein are in close agreement with those found by Greene (1918) for the salmon. They also agree closely with unpublished data for the ovaries of the carp.

\section{Organic Extractives.}

The organic extractives present in the tissue waters of all animal organs are an indirect measure of the metabolic processes in the individual tissue. Hatai (1917) has shown that the tissues of the growing white rat contain a greater proportion of extractives than those of the adult. During the migration of the king salmon Greene (1918) showed that the organic extractives 
of the muscle at first increase slightly, then remain comparatively constant in proportion to the tissue waters until late in the spawning. At the spawning when the animals are approaching death by inanition the tissue waters are less saturated. In the developing ovaries the organic extractives are of a much lower concentration than in the muscles. The percentage does not vary much during the entire migration. C. H. Greene (1919) found with respect to the muscular tissue that while the absolute amount of protein decreases, the organic extractives, especially the amino nitrogen, remain constant or increase in spite of the fact that the protein from which they are derived is constantly decreasing. The lower concentration in the ovaries would seem to be a function of the anabolic processes whereby the ovarian extractives are being synthesized into proteins. At any rate the gar muscle extractives average about 2.5 per cent while the extractives of the ovaries average about 1 per cent.

If the ratio of organic extractives to protein be figured for the series given in Table II, it will be seen that the extractives exist in the largest ratio in the youngest ovary, C11 (Table III). In C20, which contained a large number of small immature ova, the ratio is also $1: 10$. In $42 \mathrm{a}$, which was certainly the oldest specimen, the ratio is the smallest, $1: 52$. The other ratios vary in no regular order from $1: 24$ to $1: 42$. In the case of the amino nitrogen, the amounts are again certainly greatest in the youngest specimens, decreasing with maturity.

In general there is a good deal of variation in the figures for the fractions of the organic extractives; viz., total nitrogen, amino nitrogen, and creatine. In view of the relation between amino nitrogen recently pointed out by C. H. Greene (1919) it is of interest to note that the sample having the highest water content, $\mathrm{C} 11$, has also the highest value for amino nitrogen, and that the one with the lowest water, $42 \mathrm{a}$, gave with one exception the lowest value for amino nitrogen. The low value for C36 is not explained.

König and Grossfeld (1913) have studied the composition of the extractives of fish eggs, and have isolated xanthine, hypoxanthine, creatinine, taurine, and tyrosine. In view of the ease with which creatine is changed to creatinine in the manipulations of the analysis, Grindley and Woods (1906), it would seem doubtful whether there is really any preformed creatinine in fish eggs. 
Creatine was found in gar eggs in amounts varying from traces up to slightly less than $10 \mathrm{mg}$. per $100 \mathrm{gm}$. of moist sample. No especial significance is attached to this observation.

\section{The Inorganic Ash and Water.}

Our data show variations of the ash from 0.25 to 0.59 per cent, a rather extreme variation, for which there is no obvious explanation.

Water determinations were made directly on separate samples of the first seven fish but only indirectly on the others. The

\section{TABLE III.}

The Protein, Water, and Extractive Fractions Figured on a Fat-Free Basis, and Arranged in Series According to the Weights of the Ovaries.

\begin{tabular}{c|c|c|c|c|c|c|c}
\hline No. & $\begin{array}{c}\text { Weight of } \\
\text { ovary. }\end{array}$ & Protein. & $\begin{array}{c}\text { Organic } \\
\text { extrac- } \\
\text { tives. }\end{array}$ & $\begin{array}{c}\text { Ratio } \\
\text { protein: } \\
\text { extractives. }\end{array}$ & Total N. & Amino N. & Water. \\
C11 & 15.9 & 17.7 & 1.70 & $10: 1$ & 0.244 & 0.063 & 79.9 \\
C26 & 27.0 & 29.4 & 1.24 & $24: 1$ & 0.164 & 0.048 & 69.1 \\
C20 & 30.5 & 27.7 & 2.63 & $10: 1$ & 0.254 & 0.057 & 69.1 \\
C22 & 48.0 & 30.0 & 0.94 & $32: 1$ & 0.332 & 0.031 & 68.7 \\
C29 & 48.5 & 31.0 & 1.00 & $31: 1$ & 0.092 & 0.027 & 67.6 \\
C36 & 52.0 & 32.6 & 0.78 & $42: 1$ & 0.086 & 0.020 & 66.0 \\
C63 & 66.7 & 31.8 & 0.66 & $48: 1$ & 0.111 & 0.018 & 64.6 \\
C38 & 72.0 & 30.2 & 1.18 & $27: 1$ & 0.093 & 0.054 & 68.4 \\
C66 & 91.6 & 30.8 & 0.79 & $35: 1$ & 0.088 & Traces. & 70.8 \\
C78 & 94.7 & 32.0 & 1.19 & $27: 1$ & 0.168 & 0.007 & 66.0 \\
$42 a$ & $\dagger$ & 38.9 & 0.74 & $52: 1$ & 0.073 & 0.028 & 60.0 \\
\hline
\end{tabular}

* The organic extractives were obtained by subtracting the ash from the water-soluble solids.

$\dagger$ Not recorded, but the weight was several hundred grams.

water determination by differences throws the cumulative error on this fraction. Nevertheless, the agreement is quite close as between the indirect and the direct determinations on the first seven specimens.

\section{General Comparison.}

We hoped to be able to compare the composition of the gar ovaries at different stages of development. However, these fish apparently spawn over a long season and there is no way of determining the degree of development except by the general appearance and the variation in size of the ovules. In our youngest specimen, C11, 
the diameter is $1.2 \mathrm{~mm}$. In $\mathrm{C} 20$, there was the greatest variation. A few ova were as small as $0.8 \mathrm{~mm}$., while others were as much as $2.2 \mathrm{~mm}$. in diameter. $2 \mathrm{~mm}$. is the average diameter of the adult egg. In one very large fish, No. 42a, the total weight of the ovaries was estimated at 500 or $600 \mathrm{gm}$. These were the most mature in appearance of any collected. This ovary had a lower water content, the highest protein content, and a much higher amount of total fats. Broadly speaking, the protein except in the very young remains comparatively constant. The organic extractives are also constant. The total lipoids tend to increase and the total water to decrease with development of the gar ovaries.

We were not successful in securing ripe ova for analysis.

\section{BIBLIOGRAPHY.}

Albu, A., and Neuberg, C., Physiologie der Mineralstoffwechsels, Berlin, 1906.

Atwater, W. O., Rep. U. S. Com. Fish and Fisheries, 1888, 679.

Benedict, S. R., J. Biol. Chem., 1914, xviii, 183.

Buttenberg, P., Bericht des Hygien. Instituts Hamburg, 1900-02, 13; abstracted in Z. Untersuch. Nahrungs-u. Genussmittel., 1904, vii, 233.

Farnstein, K., Lendrick, H., Buttenberg, P., Kickton, A., and Klassert, M., Bericht der Nahrungsmittelkontrolle, Hamburg, 1903-04; abstracted in Z. Untersuch. Nahrungs- u. Genussmittel., 1906, xi, 742.

Folin, O., J. Biol. Chem., 1914, xvii, 469.

Greene, C. H., J. Biol. Chem., 1918, xxxiii, p. xii.

Greene, C. H., J. Biol. Chem., 1919, xxxix, 457.

Greene, C. W., J. Biol. Chem., 1909, vii, 503.

Greene, C. W., J. Biol. Chem., 1918, xxxiii, p. xiii.

Greene, C. W., J. Biol. Chem., 1921, xlviii, 59.

Grindley, H. S., and Woods, H. S., J. Biol. Chem., 1906, ii, 309.

Gulick, A., J. Biol. Chem., 1914, xviii, 541.

Hatai, S., Am. J. Anat., 1917, xxi, 23.

Janney, N. W., J. Biol: Chem., 1916, xxv, 177.

König, J., and Grossfeld, J., Biochem. Z., 1913, liv, 351.

Rimini, E., Z. Untersuch. Nahrungs- u. Genussmittel., 1904, vii, 232.

Solberg, E., Bericht der Norwegischen Landwirtschaftlichen Kontrollstation Trondheim für 1906, Christiania, 1907; abstracted in Z. Untersuch. Nahrungs- $u$. Genussmittel., 1908, xvi, 364.

Tangl, F., and Farkas, K., Arch. ges. Physiol., 1904, civ, 624.

Van Slyke, D. D., J. Biol. Chem., 1912, xii, 275.

Weitzel, A., Arb. k. Gsndhtsamte, 1916, 1, 361; abstracted in Z. Untersuch. Nahrungs- $u$. Genussmittel., 1918, xxxvi, 171. 
Vita.

I, Erwin Ellis Nelson, was born June 11, 1891, in Springfield, Missouri, the first child of my parents, Harry Anderson Nelson and Jennie Ellis Nelson. I received my early education in Springfield, graduating from the Springfield High School in 1909. The same year I entered Drury College, where I was a student until 1912, taking the premedical group of studies. The following year I was Instructor in Science in the Southern Collegiate Institute at Albion, Illinois. In 1913 I entered the University of Missouri as a senior in the College of Arts and a first year student in the School of Medicine. I received the degree of Bachelor of Arts from the University of Missouri in 1914 and in the same year the degree of Bachelor of Science from Drury College. In February 1914 I was appointed Assistant in Zoology in the University of Missouri, which position I held until June 1916. From 1914 to 1918 I was enrolled in the Graduate School of the University of Missouri, and for most of this time also in the School of Medicine. I was granted the degree of Master of Arts in 1916, my major being Zoology. From 1916 to 1918 I was University Fellow in Physiology, resigning in the second semester to become Assistant in Physiology. During the year 1918-19 I was a junior in Johns Hopkins Medical School. In 1919 I was appointed Assistant Professor of Pharmacology in the University of Michigan School of Medicine, which position I now hold. In 1920 I passed the examinations for the degree of Doctor of Philosophy at the University of Missouri. 




\section{,}


Gaylord Bros. Makers

Syracuse, N. Y. PAT. JAN. 21, 1908 
